\title{
Bir Kuaför Salonunda Risk Analizi Uygulaması
}

\author{
Risk Analysis Application in a Hair Salon \\ Meral ŞAHIN DURGUT ${ }^{1}$, Hüseyin VAPUR ${ }^{2}$
}

\section{ÖZ}

Bakım hizmetlerinin verilmiş olduğu işletmelerden biri de kuaför salonlarıdır. Ülkemizde kuaför salonları giderek büyüme gösteren sektörlerden biridir. $\mathrm{Bu}$ işletmelerde de iş sağlığı ve güvenliği açısından çeşitli tehlike ve riskler mevcuttur.

$\mathrm{Bu}$ çalışma Giresun ilinde bulunan bir kadın kuaföründe gerçekleştirilmiştir. Kuaför salonlarında çalışanların karşılaşabileceği tehlikeler ve riskler Çalışma ve Sosyal Güvenlik Bakanlığının yayınlamış olduğu kuaförler için kontrol listesi kullanılarak ve $5 \times 5$ L Tipi Matris analizi yöntemi kullanılarak analiz edilmiştir. Analiz sonucunda 14'ü katlanılamaz, 8'i önemli, 12'si orta ve 4'ü katlanılabilir olmak üzere toplamda 38 risk tespit edilmiştir. Belirlenen risklerden; kullanılan kimyasalların bilgilendirici etiketlerinin olmaması, kimyasalların depolanmasının uygunsuz olması, acil çıkış kapısı ve yönlendirmelerinin olmaması, yangın merdiveninin olmaması gibi riskler dikkat çeken yüksek skorlu riskler arasında yer almaktadır.

Çalışma sonucunda kuaför salonu sahibine kimyasalların güvenli depolanması, işletmeye ait acil durum planı ve risk analizinin yapılması, acil çıkışların oluşturularak yönlendirici işaretlemelerin yapılması önerilmiştir.

Anahtar Kelimeler: Kuaför, Tehlike, Risk Analizi

\begin{abstract}
One of the businesses where care services are provided is hairdressing salons. Hairdressing salons are one of the growing sectors in our country. There are various dangers and risks in terms of occupational health and safety in these enterprises.
\end{abstract}

This study was carried out in a women's hairdresser in Giresun. The hazards and risks that employees may encounter in hairdressing salons were analyzed using the checklist for hairdressers published by the Ministry of Labor and Social Security and using the $5 \times 5 \mathrm{~L}$ Type Matrix analysis method. As a result of the analysis, a total of 38 risks were identified, of which 14 were intolerable, 8 were significant, 12 were moderate and 4 were bearable. Of the identified risks; Risks such as the lack of informative labels of the chemicals used, the inappropriate storage of chemicals, the absence of emergency exit doors and directions, and the absence of a fire escape are among the high-scoring risks.

As a result of the study, it was suggested to the owner of the hairdresser that the chemicals should be stored safely, the emergency plan and risk analysis of the enterprise should be made, emergency exits should be created and guiding signs should be made.

Keywords: Hairdresser, Hazard, Risk Analys

\footnotetext{
${ }^{1}$ Öğr. Gör., Meral ŞAHİN DURGUT, İş Sağlığı ve Güvenliği, Giresun Üniversitesi, Espiye Meslek Yüksekokulu, Mülkiyet Koruma ve Güvenlik Bölümü, meral.sahin@ giresun.edu.tr, ORCID: 0000-0002-9287-2839

2 Prof. Dr., Hüseyin VAPUR, Maden Mühendisliği, Çukurova Üniversitesi Mühendislik Fakültesi, Maden Mühendisliği Bölümü, hvapur@cu.edu.tr, ORCID:0000-0003-4438-3982 


\section{GíRiş}

Çeşitli bakım hizmetlerinin verilmiş olduğu işletmelerden biri de kuaför salonlarıdır. Bir kuaför salonunda genel olarak 1-10 kişi çalışmaktadır. Ülkemizde kuaför salonları giderek büyüme gösteren sektörlerden biri olup 25 bin kadın kuaförü ve 30 bin civarında erkek kuaförü mevcuttur. ${ }^{1}$ Dünya çapında üç milyon civarında kuaför bulunmaktadır. Ancak sayıca çok bulunan ve bakım hizmeti alınan bu işletmelerde iş sağlığı ve güvenliği açısından çeşitli tehlikeler ve riskler vardır.

Kuaförlerin maruz kaldı ğ1/kalabileceği mesleki tehlike ve riskler arasında fiziksel, kimyasal, biyolojik, ergonomik, psikososyal ve elektriksel tehlike ve risklerin yanında, hijyen, düşme-kayma durumları, yanıklarkesikler ve yangın yer almaktadır. ${ }^{1}$ Avrupa İş Güvenliği ve Sağlığı Ajansı, kuaförlerde ciddi iş sağlığı risklerine maruz kalındığını bu yüzden çalışma şartlarının iyileştirilmesinin büyük bir öncelik olması gerektiğini kabul etmiştir. ${ }^{1,2}$

Kuaför salonları standardın altında olan işletmelerdir ${ }^{3}$ ve gerçekleştirilen bakım hizmetlerinden kaynaklı çeşitli maruziyetler söz konusudur., ${ }^{4,5} \mathrm{Bu}$ maruziyetlere örnek olarak; kullanılan saç spreyleri, boyalar, saç rahatlatıcı kremler ve şampuanlar gibi kozmetik ancak kimyasal ürünler ile ergonomik olmayan çalışma duruşları gösterilebilir. ${ }^{5,6,7}$ Nijerya'da kuaför salonlarındaki çalışma ortamının sağlık üzerindeki etkilerinin değerlendirildiği ve 355 katılımın sağlandığı bir çalışmada; iki yüz elli beş katılımcı işlerinin kendilerini sağlık risklerine maruz biraktığını bildirmiştir. Aynı çalışmada 89 katılımcı uzun süre ayakta kaldıklarını, 31 katılımcı uzun çalışma saatlerinin olduğunu, 76 katılımcı ise eklem ağrıları olduğunu bildirmiştir. ${ }^{4}$ Başka bir çalışmada kuaförlere yönelik ergonomik risk analizleri yapılmış, çalışmaya dâhil edilen işlemlerin 2'si yüksek riskli tespit edilmiş ve vücudun hizmet sunumu esnasında maruz kaldığ 1 ergonomik zorlanma düzeyleri ortaya konmuştur. ${ }^{5}$
Brezilyada gerçekleştirilen bir çalışmada, katılımcıların büyük çoğunluğu çalışma ortamlarında gürültü olduğunu, kullanılan eşya ve mobilyaların uygun olmadiğını ve işleri ile ilgili olarak en çok sırası ile omuz bölgesi, boyun bölgesi ve sirt bölgesinde zorlanmalarının olduğunu dile getirmişlerdir. ${ }^{6}$ Avustralya' da gerçekleştirilen başka bir çalışmada ise, kuaför salonlarında eldiven kullanımının yetersiz olduğu, çalışanlarda kullanılan kozmetik ürün içeriklerinden dolayı alerjilerin gelişebileceği, çalışma alanında ıslak çalışmaya maruz kalmanın söz konusu olduğu gibi tehlikeler bildirilmiştir. ${ }^{8}$

Kuaförlük ve diğer güzellik salonlarının faaliyetleri kapsamında ilgili sektörde bulunan tehlikelerin ve risklerin ülkemiz Sosyal Güvenlik Kurumu istatistiklerine yansıması şu şekildedir: ${ }^{9}$

2014 de 35 sigortal1, 2015 de 49 sigortal1, 2016 da 50 sigortal1, 2017 de 89 sigortal,, 2018 de 122 sigortalı ve 2019 da 137 sigortalı iş kazası yaşamıştır. Ancak yıllara bağlı yaşanan meslek hastalıkları sayısı incelendiğinde tanısı konulabilen ve kayda geçen 2014-2017 yılları arasında 0, 20182019 y1llarında 1'er olmak üzere toplamda 2 çalışan meslek hastalığına yakalanmıştır. ${ }^{9}$

Gerçekleştirilen bu araştırma ve istatistik sonuçlarına göre kuaför salonlarında mevcut olan tehlikelerin ve risklerin değerlendirilmesi ile önlemlerin hayata geçirilmesi bir zorunluluk olarak karşımıza çıkmaktadır.

Ülkemizde 2012'de çıkartılan 6331 sayılı yasaya göre işverenin yapmakla yükümlü olduğu olgular vardır ve bunlardan biri de, çalışanlarının işletme içerisinde maruz kalabileceği tehlikeleri ve riskleri değerlendirmektir. ${ }^{10} \mathrm{Bu}$ kapsamda kuaför işletmeleri, 96.02 kodu ve kuaförlük ve diğer güzellik salonlarının faaliyetleri başlığı ile Issyerlerinde Tehlike Sinıfi Tebliğine göre tehlikeli sinıfta yer alan işletmelerden sayılmaktadır. ${ }^{11}$ 'Tehlikeli' işyeri tehlike sınıfında yer alan kuaförler gibi işyerlerinde 
yasal mevzuat gereği en geç 4 yılda bir defa olmak üzere risk değerlendirme sürecinin güncellenmesi ve yenilenmesi gerekmektedir. ${ }^{10,12}$

Risk değerlendirmesi tehlikeleri tanımlamak, riskleri belirlemek, riskleri analiz etmek, risk kontrol adımlarını uygulamak, dokümantasyon ve risk değerlendirmesini yenilemek gibi adımlardan oluşur. $^{12}$

Literatür incelendiğinde risk analiz yöntemleri iki ana gruba ayrılır (Kalitatif, kantitatif). Kantitatif risk analiz yöntemlerinde, risk hesaplanırken sayısal yöntemlere başvurulur. Kalitatif risk analizinde tehdidin olma olasılığı, tehdidin etkisi gibi değerlere sayısal değerler verilir, bu değerler mantıksal, matematiksel metotlarla proses edilip risk değeri bulunur. ${ }^{13}$

$\mathrm{Bu}$ risk analizi çalışması ile kuaför salonlarında yer alan ve yer almayıp dışarıdan gelebilecek tehlikelerin tespiti ile bu tehlikelerden kaynaklanması muhtemel risklerin belirlenmesi ve bir dizi güvenlik önlemlerinin önerilmesi amaçlanmıştır.

\section{MATERYAL VE METOT}

Mevzuat incelendiğinde risklerin, ulusal veya uluslararası standartlardan seçilen yöntemlerden birinin ya da birkaçının birlikte kullanılarak analiz edilebileceği belirtilmiş olup hangi yöntemin kullanılacağı ile ilgili seçenek analiste bırakılmıştır.

Kuaför salonlarında dışarıdan gelebilecek yahut var olan tehlikeleri belirlemek için bakanlığın yayımladığı kontrol listesi kullanılmıştır. ${ }^{14}$

Kontrol listesinde genel, tertip-düzen, elektrik, makinalar, yangın, kimyasal maddeler, kesici ve delici aletler, ergonomi ve monoton çalışma, sterilizasyon, psikososyal etkenler, eğitim ve bilgilendirme, kazalar ve hastalıklar olarak toplamda 12 tehlike/risk başlığı bulunmaktadır. $\mathrm{Bu}$ çalışmada yöntem olarak gerekli doküman ihtiyacının çok az olması ve tek analist ile uygulanabilmesinden dolayı L tipi $(5 \times 5)$ matris yöntemi kullanılmıştır.

L tipi matris yönteminde risk aşağıdaki formül ile hesaplanır:

Risk Puanı $=$ İhtimal $\times$ Zarar Derecesi
Tablo 1. Tehlikenin İhtimali (Meydana Gelmesi)

\begin{tabular}{|c|c|}
\hline İHTIMMAL & $\begin{array}{c}\text { TEHLIKENIN MEYDANA } \\
\text { GELMESİ İÇIN } \\
\text { DERECELENDİRME } \\
\text { BASAMAKLARI }\end{array}$ \\
\hline Çok küçük & Hemen hemen hiç \\
\hline Küçük & $\begin{array}{l}\text { Y1lda bir kez (çok az), sadece } \\
\text { anormal durumlarda }\end{array}$ \\
\hline Orta & Y1lda birkaç kez (az) \\
\hline Yüksek & Ayda bir (sıklıkla) \\
\hline Çok yüksek & $\begin{array}{l}\text { Haftada bir, her gün (çok sıklıkla), } \\
\text { normal çalışma şartlarında }\end{array}$ \\
\hline
\end{tabular}

Tehlikenin ihtimali (meydana gelmesi) Tablo 1'de görülen L tipi risk analiz yöntemi olasılık derecelendirmesine göre belirlenmiştir. Bu tabloda çok küçük 1 puanı, çok yüksek 5 puanı temsil etmektedir.

Tablo 2. Tehlikenin Olması Durumunda Şiddeti

\begin{tabular}{ll}
\hline \multicolumn{1}{c}{ SONUÇ } & \multicolumn{1}{c}{ DERECELENDİRME } \\
\hline Çok hafif & Ilk yardım gerektiren, iş saati kaybı yok \\
\hline Hafif & $\begin{array}{l}\text { Kalıcı etkisi olmayan, iş günü kaybı } \\
\text { olmayan, ilk yardım gerektiren, ayakta } \\
\text { tedavi gerektiren }\end{array}$ \\
\hline Orta & $\begin{array}{l}\text { Yatarak tedavi gerektiren, hafif } \\
\text { yaralanma yaşatan }\end{array}$ \\
\hline Ciddi & $\begin{array}{l}\text { Uzun süreli tedavi, ciddi yaralanma, } \\
\text { meslek hastalığı }\end{array}$ \\
\hline Çok ciddi & Sürekli iş göremezlik, ölüm \\
\hline
\end{tabular}

Her bir tehlike için şiddet derecelendirilmesi, Tablo 2'de görülen L tipi risk analiz yöntemi şiddet derecelendirmesi dikkate alınarak belirlenmiştir. Bu tabloda çok hafif 1 puanı, çok ciddi 5 puanı temsil etmektedir. 
Belirlenen ihtimal ve şiddet değerleri belirtilen formül uygulanarak risk skorları hesaplanmıştır. Risklerin kabul edilebilirlik boyutlarını belirlemede ise Tablo 3'te görülen L tipi karar matrisi kullanılmıştır. Bu tabloda risk skorları 1 yeşil (anlamsız riskler), 2 - 6 arası yeşil renk (katlanılabilir riskler), 8 - 12 arası sarı renk (orta düzeydeki riskler) ve 15 - 20 arası kırmızı renk (önemli riskler) 25 kırmızı (katlanılamaz riskler) olarak belirlenmiștir.

Tablo 3. L Tipi Matris İçin Risk Derecelendirme Matrisi

\begin{tabular}{lllllll}
\hline & & \multicolumn{5}{c}{ SONUÇ ( ŞíDDET ) } \\
\cline { 2 - 6 } OLASILIK & 5 & 4 & 3 & 2 & 1 \\
\cline { 3 - 6 } & & $\begin{array}{l}\text { Çok } \\
\text { ciddi }\end{array}$ & Ciddi & Orta & Hafif & $\begin{array}{c}\text { Çok } \\
\text { hafif }\end{array}$ \\
\hline 5 & $\begin{array}{l}\text { Çok } \\
\text { yüksek }\end{array}$ & 25 & 20 & 15 & 10 & 5 \\
\hline 4 & Yüksek & 20 & 16 & 12 & 8 & 4 \\
\hline 3 & Orta & 15 & 12 & 9 & 6 & 3 \\
\hline 2 & Küçük & 10 & 8 & 6 & 4 & 2 \\
\hline 1 & $\begin{array}{l}\text { Çok } \\
\text { küçük }\end{array}$ & 5 & 4 & 3 & 2 & 1 \\
\hline
\end{tabular}

Son adımda, Tablo 4 kullanılmış risk puanlarının değerlerine göre, sonucun kabul edilebilirlik değerleri belirlenmiș, riskin büyüklüğüne göre alınması gereken önlemlerin önceliğine karar verilmiştir.
Tablo 4. Risk Sonucunun Kabul Edilebilirlik Değerleri

\begin{tabular}{|c|c|}
\hline SONUÇ & EYLEM \\
\hline $\begin{array}{l}\text { Katlanılamaz } \\
\text { Riskler ( } 25 \text { ) }\end{array}$ & $\begin{array}{l}\text { Belirlenen risk kabul edilebilir bir } \\
\text { seviyeye düşürülünceye dek iş, } \\
\text { başlatılmamalı, devam eden bir } \\
\text { faaliyet varsa derhal } \\
\text { durdurulmalıdır. Gerçekleştirilen } \\
\text { faaliyetlere rağmen riski } \\
\text { düşürmek mümkün olmuyorsa, } \\
\text { faaliyet engellenmelidir. }\end{array}$ \\
\hline $\begin{array}{l}\text { Önemli } \\
\text { Riskler } \\
(\mathbf{1 5 , 1 6 , 2 0})\end{array}$ & $\begin{array}{l}\text { Belirlenen risk azaltılıncaya } \\
\text { kadar iş başlatılmamalı eğer } \\
\text { devam eden bir faaliyet varsa } \\
\text { hemen durdurulmalıdır. Risk işin } \\
\text { devam etmesi ile ilgiliyse acil } \\
\text { önlem alınmalı ve bu önlemler } \\
\text { sonucunda devam edip } \\
\text { etmeyeceğine karar verilmelidir. }\end{array}$ \\
\hline $\begin{array}{l}\text { Orta } \\
\text { Düzeydeki } \\
\text { Riskler } \\
(\mathbf{8 , 9 , 1 0 , 1 2 )}\end{array}$ & $\begin{array}{l}\text { Tespit edilen riskleri düşürmek } \\
\text { için faaliyetler başlatılmalıdır. }\end{array}$ \\
\hline $\begin{array}{l}\text { Katlanılabilir } \\
\text { Riskler } \\
(2,3,4,5,6)\end{array}$ & $\begin{array}{l}\text { Belirlenen riskleri } \\
\text { kaldırmak adına ek kontrol } \\
\text { proseslerine ihtiyaç olmayabilir. } \\
\text { Ancak mevcut kontrollerin } \\
\text { sürdürüldüğ̈ denetlenmelidir. }\end{array}$ \\
\hline $\begin{array}{l}\text { Önemsiz } \\
\text { Riskler ( } 1 \text { ) }\end{array}$ & $\begin{array}{l}\text { Belirlenen riskleri ortadan } \\
\text { kaldırmak için kontrol prosesleri } \\
\text { planlamaya ve gerçekleştirilecek } \\
\text { faaliyetlerin } \\
\text { saklamaya gerek olmayabilir. }\end{array}$ \\
\hline
\end{tabular}

\section{Araştırmanın Etik Yönü}

Araştırmanın gerçekleştirilebilmesi için Giresun ilinde bir kadın kuaföründen yazılı izin ve Gümüşhane Üniversitesi Bilimsel Araştırma ve Yayın Etiği Kurulundan etik kurul onay belgesi alınmıştır.

\section{BULGULAR VE TARTIŞMA}

Bir kadın kuaföründe gerçekleştirilen bu çalışmada L tipi Matris risk analiz yöntemi ile bir risk analiz çalışması gerçekleştirilmiştir. Gerçekleştirilen analiz çalışmasına ilişkin sonuçlar Tablo 5'te yer almaktadır. 
Tablo 5. Gerçekleştirilen Risk Analizi

\begin{tabular}{|c|c|c|c|c|c|c|c|c|}
\hline & $\begin{array}{c}\text { Sira } \\
\text { No }\end{array}$ & Tehlike & Risk & Olasılık & Şiddet & Risk & $\begin{array}{c}\text { Risk } \\
\text { Sonucu }\end{array}$ & Tavsiye Edilen Önlemler \\
\hline$\frac{v}{\frac{V}{E}}$ & 1 & $\begin{array}{l}\text { Elektrik/sigorta } \\
\text { kutularının } \\
\text { herkesçe } \\
\text { erişilebilir } \\
\text { olması }\end{array}$ & $\begin{array}{c}\text { *Kaza } \\
\text { *Yaralanma } \\
\text { *Elektrik } \\
\text { Çarpması } \\
\text { *Yangın }\end{array}$ & 5 & 5 & 25 & 焉 & $\begin{array}{l}\text { *Elektrik/sigorta kutularının } \\
\text { olası olumsuzlukların önüne } \\
\text { geçebilmek adına sorumlusu } \\
\text { tarafından erişilebilir olmalıdır. } \\
\text { *Elektrik/sigorta kutuları kilitli } \\
\text { vaziyette bulundurulmalıdır. }\end{array}$ \\
\hline 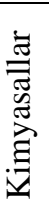 & 2 & $\begin{array}{l}\text { Kimyasallarin } \\
\text { bilgilendirici } \\
\text { etiketlerinin } \\
\text { olmaması }\end{array}$ & $\begin{array}{c}\text { *Tahriş } \\
\text { *Kaza } \\
\text { *Yaralanma }\end{array}$ & 5 & 5 & 25 & 胥 & $\begin{array}{l}\text { *Kimyasalların üzerinde } \\
\text { uygulama yöntemini, tehlike } \\
\text { sınıfını ve zararlarını ifade } \\
\text { eden etiketlendirmelerin yer } \\
\text { alması gerekmektedir. }\end{array}$ \\
\hline ষ্ঠে & 3 & $\begin{array}{l}\text { İşyerinde risk } \\
\text { analizi ve acil } \\
\text { durum planı } \\
\text { yapılmamış } \\
\text { olması }\end{array}$ & $\begin{array}{l}\text { *Acil durumda } \\
\text { müdahalenin } \\
\text { belirlenmemiş } \\
\text { olması } \\
\text { *Can ve mal } \\
\text { kaybı }\end{array}$ & 5 & 5 & 25 & 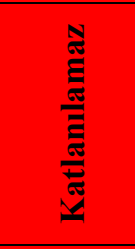 & $\begin{array}{c}\text { *İsyerlerinde ilgili mevzuat } \\
\text { uyarınca acil durumların } \\
\text { belirlenmesi ve acil } \\
\text { durumlarda yapılması } \\
\text { gerekenlerin belirlenmesi } \\
\text { gerekmektedir. }\end{array}$ \\
\hline$\underset{0}{\stackrel{0}{0}}$ & 4 & $\begin{array}{c}\text { Binanın tek } \\
\text { giriş kapısının } \\
\text { olması }\end{array}$ & $\begin{array}{c}\text { *Acil } \\
\text { durumlarda } \\
\text { izdiham } \\
\text { *Kaza } \\
\text { *Yaralanma } \\
\text { *Can ve mal } \\
\text { kaybı }\end{array}$ & 5 & 5 & 25 & है & $\begin{array}{l}\text { *Acil durumlarda olabilecek } \\
\text { izdiham durumuna karşı } \\
\text { tahliyeyi kolaylaştırmak için } \\
\text { panik kollu, dışarı açılan, kilitli } \\
\text { olmayan, sadece acil durumlar } \\
\text { için oluşturulmuş ve uygun } \\
\text { nitelikte etiketlenmiş acil } \\
\text { durum kapısı olmalıdır. }\end{array}$ \\
\hline 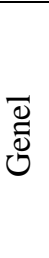 & 5 & $\begin{array}{l}\text { Acil çıkış } \\
\text { yönlendirme } \\
\text { levhalarının } \\
\text { olmaması }\end{array}$ & $\begin{array}{c}\text { *Acil } \\
\text { durumlarda } \\
\text { izdiham *Kaza } \\
\text { *Yaralanma } \\
\text { *Can ve mal } \\
\text { kayb1 }\end{array}$ & 5 & 5 & 25 & 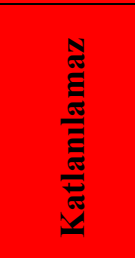 & $\begin{array}{l}\text { *Acil durumlarda tahliyeyi } \\
\text { kolaylaştırmak için bina ve } \\
\text { işyeri içerisinde acil çıkış } \\
\text { yönlendirme levhalarının yeter } \\
\text { sayıda konulması } \\
\text { gerekmektedir. }\end{array}$ \\
\hline 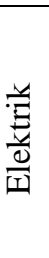 & 6 & $\begin{array}{l}\text { Elektrik/sigorta } \\
\text { kutularının } \\
\text { önünde } \\
\text { yalıtkan paspas } \\
\text { olmaması }\end{array}$ & $\begin{array}{c}\text { *Kaza } \\
\text { *Yaralanma } \\
\text { *Elektrik } \\
\text { Çarpması } \\
\text { *Yangın } \\
\text { *Ölüm }\end{array}$ & 5 & 4 & 20 & 苞 & $\begin{array}{c}\text { *Elektrik/sigorta kutuları } \\
\text { önlerine yalıtkan paspas } \\
\text { konulmalıdır. } \\
\text { *Elektrik tehlikesini belirten } \\
\text { uyarı etiketi ilgili yere } \\
\text { yapıştırılmalıdır. }\end{array}$ \\
\hline$\underset{D}{\Xi}$ & 7 & $\begin{array}{c}\text { Kimyasal } \\
\text { maddelerin } \\
\text { tehlike sınıfına } \\
\text { uygun ayrı } \\
\text { depolanmaması }\end{array}$ & $\begin{array}{l}\text { *Kimyasalların } \\
\text { etkileşimi } \\
\text { *Kaza } \\
\text { *Yaralanma } \\
\text { *Patlama } \\
\text { *Yangın } \\
\text { *Çevre } \\
\text { Kirliliği } \\
\end{array}$ & 5 & 4 & 20 & है & $\begin{array}{l}\text { *Kullanılan kimyasallar ısı ve } \\
\text { 1şık almayan çalışma alanından } \\
\text { ayrı bir yerde depolanmalıdır. } \\
\text { *Kimyasal depolama matrisine } \\
\text { göre uygun tehlike sınıfı } \\
\text { ayrımı gözetilerek depolama } \\
\text { yapılmalıdır. }\end{array}$ \\
\hline 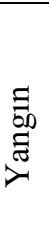 & 8 & $\begin{array}{c}\text { Kimyasal } \\
\text { maddelerin } \\
\text { çalışma } \\
\text { alanında } \\
\text { depolanması }\end{array}$ & $\begin{array}{l}\text { *Kimyasalların } \\
\text { devrilmesi, } \\
\text { dökülmesi } \\
\text { *Kaza } \\
\text { *Yaralanma } \\
\text { *Yangın }\end{array}$ & 5 & 4 & 20 & 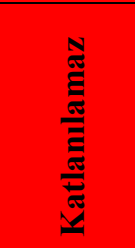 & $\begin{array}{l}\text { *Kullanılan kimyasallar ısı ve } \\
\text { 1şık almayan çalışma alanından } \\
\text { ayrı bir yerde depolanmalıdır. } \\
\text { *Kimyasallar orijinal } \\
\text { kutularında ve en az miktarda } \\
\text { bulundurulmalıdır. }\end{array}$ \\
\hline
\end{tabular}


Tablo 5. (Devamı) Gerçekleştirilen Risk Analizi

\begin{tabular}{|c|c|c|c|c|c|c|c|c|}
\hline$\underset{D}{\stackrel{\Xi}{\Xi}}$ & 9 & $\begin{array}{l}\text { Acil durum } \\
\text { telefon } \\
\text { numaralarının } \\
\text { asılı olmaması }\end{array}$ & $\begin{array}{l}\text { *Yangin } \\
\text { *Kaza } \\
\text { *Ölüm }\end{array}$ & 4 & 5 & 20 & 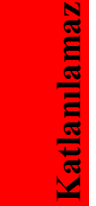 & $\begin{array}{l}\text { *Acil durumlara ilişkin telefon } \\
\text { numaraları herkesçe görülebilir } \\
\text { bir alanda asılı olmalıdır. }\end{array}$ \\
\hline$\underset{\Xi}{\stackrel{\Xi}{\Xi}}$ & 10 & $\begin{array}{c}\text { Yangın } \\
\text { söndürme } \\
\text { tüpünün } \\
\text { tarihinin } \\
\text { geçmiş olması }\end{array}$ & $\begin{array}{l}\text { *Yangın } \\
\text { *Kaza } \\
\text { *Ölüm }\end{array}$ & 4 & 5 & 20 & 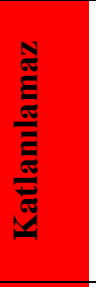 & $\begin{array}{l}\text { *Yangın acil durumunda olaya } \\
\text { müdahale edebilmek için } \\
\text { yangın söndürme tüpü yeter } \\
\text { sayıda bulundurulmalıdır. } \\
\text { *Yangın söndürme tüpü } \\
\text { herkesçe görülebilir bir alanda } \\
\text { yer almalıdır. }\end{array}$ \\
\hline$\underset{\Xi}{\stackrel{\Xi}{\Xi}}$ & 11 & $\begin{array}{c}\text { Yangın } \\
\text { söndürme } \\
\text { tüpünün } \\
\text { yerinin uygun } \\
\text { olmaması }\end{array}$ & $\begin{array}{l}\text { *Yangının } \\
\text { Büyümesi } \\
\text { *Kaza } \\
\text { *Ölüm }\end{array}$ & 4 & 5 & 20 & 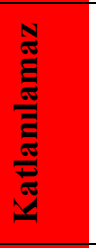 & $\begin{array}{c}\text { *Yangın söndürme tüpü } \\
\text { mevuzata göre; yerden } \\
\text { maksimum } 90 \text { santimetre } \\
\text { yukarıda, herkesçe görülebilir } \\
\text { ve ulaşılabilir olması } \\
\text { sağlanmalıdır. }\end{array}$ \\
\hline$\underset{\Xi}{\stackrel{\Xi}{\Xi}}$ & 12 & $\begin{array}{l}\text { Binada yangin } \\
\text { merdiveninin } \\
\text { olmaması }\end{array}$ & $\begin{array}{l}\text { *Yaralanma } \\
\text { *İzdiham } \\
\text { *Ölüm } \\
\text { *Tahliye } \\
\text { olunamaması }\end{array}$ & 4 & 5 & 20 & 苞 & $\begin{array}{l}\text { *Binada acil durumlarda } \\
\text { tahliye olunabilmesi için } \\
\text { yangın merdiveni olmalıdır. }\end{array}$ \\
\hline 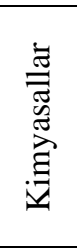 & 13 & $\begin{array}{l}\text { Kimyasalların } \\
\text { malzeme } \\
\text { güvenlik bilgi } \\
\text { formlarının } \\
\text { olmaması }\end{array}$ & $\begin{array}{l}\text { *Acil } \\
\text { durumlarda bilgi } \\
\text { eksikliği }\end{array}$ & 4 & 5 & 20 & 苞 & $\begin{array}{l}\text { *Kullanılan kimyasalların } \\
\text { içerik ve acil durum bilgilerini } \\
\text { içeren malzeme güvenlik bilgi } \\
\text { formları olmalıdır. }{ }^{* B u} \\
\text { formlara çalışanların kolay } \\
\text { erişebilmesi sağlanmalıdır. }\end{array}$ \\
\hline 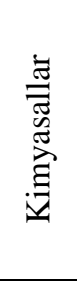 & 14 & $\begin{array}{l}\text { Kimyasalların } \\
\text { kullanımı } \\
\text { esnasında } \\
\text { kişisel } \\
\text { koruyucu } \\
\text { donanım } \\
\text { kullanılmaması } \\
\end{array}$ & $\begin{array}{l}\text { *Tahriş } \\
\text { *Kaza } \\
\text { *Yaralanma }\end{array}$ & 4 & 5 & 20 & 苞 & $\begin{array}{l}\text { *Kimyasal kullanımı esnasında } \\
\text { solunumu korumak için uygun } \\
\text { maske, elleri korumak için } \\
\text { uygun eldiven vb. gerekli } \\
\text { koruyucular kullanılmalıdır. }\end{array}$ \\
\hline 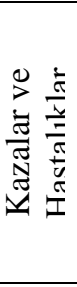 & 15 & $\begin{array}{l}\text { Ilk yardım } \\
\text { dolabında } \\
\text { yeterli } \\
\text { malzeme } \\
\text { olmaması }\end{array}$ & $\begin{array}{l}\text { *Yaralanma/kaza } \\
\text { durumlarina } \\
\text { müdahale } \\
\text { edememe }\end{array}$ & 4 & 4 & 16 & : & $\begin{array}{l}\text { *Acil durumlarda kullanılmak } \\
\text { üzere ilk yardım dolabında } \\
\text { yeterli malzeme } \\
\text { bulundurulmalıdır. } \\
\text { *Malzemelerin son kullanma } \\
\text { tarihleri sorumlu tarafindan } \\
\text { kontrol edilmelidir. }\end{array}$ \\
\hline 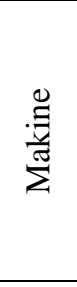 & 16 & $\begin{array}{l}\text { Saç kurutma ve } \\
\text { pedikür } \\
\text { makinelerinin } \\
\text { zemin sslak } \\
\text { iken de } \\
\text { kullanıliyor } \\
\text { olması } \\
\end{array}$ & $\begin{array}{l}\text { *Kaza } \\
\text { *Yaralanma } \\
\text { *Elektrik } \\
\text { Çarpması } \\
\text { *Yangın } \\
\text { *Ölüm }\end{array}$ & 4 & 4 & 16 & : & $\begin{array}{l}\text { *Elektrikli makineler nemli } \\
\text { 1slak ve kimyasal ortamla } \\
\text { temas olabilecek alanlarda } \\
\text { kullanılmamalıdır. }\end{array}$ \\
\hline 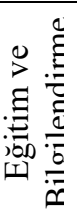 & 17 & $\begin{array}{l}\text { Çalışanların ilk } \\
\text { yardım } \\
\text { konusunda } \\
\text { eğitiminin } \\
\text { olmaması }\end{array}$ & $\begin{array}{l}\text { *Riskli davranış } \\
\text { biçimleri } \\
\text { *Hastalık } \\
\text { *Yaralanma }\end{array}$ & 4 & 4 & 16 & : & $\begin{array}{l}\text { *Çalışanların ilk yardım } \\
\text { konusunda eğitim alması } \\
\text { sağlanmalıdır. }\end{array}$ \\
\hline
\end{tabular}


 \\ Tablo 5. (Devamı) Gerçekleştirilen Risk Analizi}

\begin{tabular}{|c|c|c|c|c|c|c|c|c|}
\hline 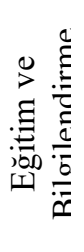 & 18 & $\begin{array}{l}\text { Çalışanların } \\
\text { temel iş sağlığ } \\
\text { ve güvenliği } \\
\text { konusunda } \\
\text { eğitiminin } \\
\text { olmaması }\end{array}$ & $\begin{array}{c}\text { *Riskli } \\
\text { davranış } \\
\text { biçimleri } \\
\text { *Hastalık } \\
\text { *Yaralanma }\end{array}$ & 4 & 4 & 16 & : & $\begin{array}{l}\text { *Çalışanların temel iş sağllı̆ı ve } \\
\text { güvenliği konusunda eğitim } \\
\text { alması sağlanmalıdır. }\end{array}$ \\
\hline 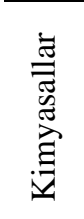 & 19 & $\begin{array}{l}\text { Kimyasal } \\
\text { kullanımı } \\
\text { esnasında doğal } \\
\text { havalandırmanın } \\
\text { yetersiz olması }\end{array}$ & $\begin{array}{l}\text { *Solunum } \\
\text { Güçlüğ̈̈ } \\
\text { *Havasızlık } \\
\text { *Yaralanma }\end{array}$ & 5 & 3 & 15 & ठ̄ & $\begin{array}{l}\text { *Uygulama alanının küçük } \\
\text { olmasından dolayı kimyasalların } \\
\text { kullanımı esnasında ortaya çıkan } \\
\text { kokunun giderilmesi için yapay } \\
\text { havalandırma desteği olmalıdır. }\end{array}$ \\
\hline 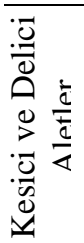 & 20 & $\begin{array}{l}\text { Makas ve } \\
\text { cımbız gibi } \\
\text { kesici delici } \\
\text { aletlerin açıkta } \\
\text { bulunması }\end{array}$ & $\begin{array}{c}\text { *Kaza } \\
\text { *Yaralanma }\end{array}$ & 5 & 3 & 15 & :" & $\begin{array}{l}\text { *Kesici delici aletler kapalı } \\
\text { yerlerde ve koruyucu kılıflar ile } \\
\text { muhafaza edilmelidir. } \\
\text { *Yetkisiz kişilerin bu aletlere } \\
\text { teması önlenmelidir. }\end{array}$ \\
\hline $\begin{array}{l}\bar{\otimes} \\
\stackrel{0}{0}\end{array}$ & 21 & $\begin{array}{l}\text { Binanın engelli } \\
\text { bireylerin } \\
\text { kullanımına } \\
\text { uygun olmaması }\end{array}$ & $\begin{array}{c}\text { *Düşme } \\
\text { *Yaralanma }\end{array}$ & 5 & 3 & 15 & ठ̄ & $\begin{array}{l}\text { *Bina giriş katına engelli } \\
\text { bireylerin de kullanabileceği } \\
\text { ölçüde asansör yapılmalıdır. }\end{array}$ \\
\hline 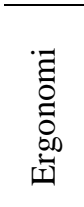 & 22 & $\begin{array}{l}\text { Çalışanların } \\
\text { uzun süre aynı } \\
\text { pozisyonda } \\
\text { çalışması }\end{array}$ & $\begin{array}{c}\text { *Meslek } \\
\text { Hastalığ1 } \\
\text { *Kas iskelet } \\
\text { sistemi } \\
\text { rahatsızlıkları }\end{array}$ & 5 & 3 & 15 & ठً & $\begin{array}{c}\text { *Çalışanların uzun süre aynı } \\
\text { pozisyonda çalışması } \\
\text { engellenmelidir. Düzenli ara } \\
\text { dinlenmeler ve iş değişiklikleri } \\
\text { yapılmalıdır. }\end{array}$ \\
\hline 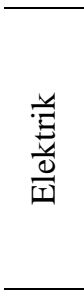 & 23 & $\begin{array}{l}\text { Elektrik priz ve } \\
\text { kablolarının } \\
\text { sağlamlığının } \\
\text { düzenli olarak } \\
\text { takip } \\
\text { edilmemesi }\end{array}$ & $\begin{array}{l}\text { *Kaza } \\
\text { *Yaralanma } \\
\text { *Elektrik } \\
\text { Çarpması } \\
\text { *Yangın } \\
\text { *Ölüm }\end{array}$ & 3 & 4 & 12 & $\stackrel{\pi}{0}$ & $\begin{array}{l}\text { *Elektrik priz ve kablolarının } \\
\text { sağlam olup olmadığı sorumlu } \\
\text { tarafından düzenli olarak takip } \\
\text { edilmelidir. *Nemli, 1slak } \\
\text { zeminle kablo temasını önlemek } \\
\text { için kablo kanalı uygulaması } \\
\text { yapılmalıdır. }\end{array}$ \\
\hline ब্ঠ & 24 & $\begin{array}{c}\text { Yüksek } \\
\text { dolapların } \\
\text { duvara } \\
\text { sabitlenmemesi }\end{array}$ & $\begin{array}{l}\text { *Devrilme } \\
\text { *Düşme } \\
* \text { Can ve Mal } \\
\text { Kaybı }\end{array}$ & 2 & 5 & 10 & ڤึ & $\begin{array}{l}\text { *Yüksek dolapların olası acil } \\
\text { durumlarda devrilme riskine } \\
\text { karşı sabitlenmesi gerekmektedir. }\end{array}$ \\
\hline 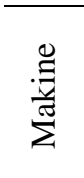 & 25 & $\begin{array}{c}\text { A ̆gda } \\
\text { makinesine ve } \\
\text { 1sitılmış ağdaya } \\
\text { temas }\end{array}$ & $\begin{array}{l}* \text { Kaza } \\
* \text { Yanık }\end{array}$ & 5 & 2 & 10 & 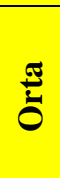 & $\begin{array}{l}\text { *Ağda makinesi ağda 1sıtıldıktan } \\
\text { sonra kapatılmalıdır. *Kullanım } \\
\text { esnasında kişisel koruyucu } \\
\text { donanım kullanılmalıdır. }\end{array}$ \\
\hline$\frac{\mathscr{\Xi}}{\stackrel{\Xi}{\Xi}}$ & 26 & $\begin{array}{l}\text { Şofben } \\
\text { kullanımında } \\
\text { kaynar suya } \\
\text { temas }\end{array}$ & $\begin{array}{l}\text { *Kaza } \\
* \text { Yanık }\end{array}$ & 5 & 2 & 10 & $\stackrel{\pi}{0}$ & $\begin{array}{c}\text { *Şofben kullanımında ilk etapta } \\
\text { su 1lık ayarda açılmalıdır. } \\
\text { *Kullanım esnasında kişisel } \\
\text { koruyucu donanım } \\
\text { kullanılmalıdır. } \\
\end{array}$ \\
\hline 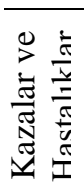 & 27 & $\begin{array}{l}\text { Çalışanlara } \\
\text { tetanos } \\
\text { bağı̆şıklığının } \\
\text { sağlanmaması }\end{array}$ & $\begin{array}{l}\text { *Bulaşıc1 } \\
\text { hastalık } \\
* \text { Meslek } \\
\text { Hastalı̆̆ } 1\end{array}$ & 3 & 3 & 9 & 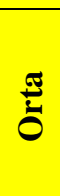 & $\begin{array}{l}\text { *Çalışanlarda tetanos } \\
\text { bağışıklığının sağlanması } \\
\text { gereklidir. }\end{array}$ \\
\hline 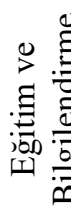 & 28 & $\begin{array}{l}\text { Çalışanların } \\
\text { hijyen ve Covid- } \\
19 \text { konusunda } \\
\text { eğitiminin } \\
\text { olmaması }\end{array}$ & $\begin{array}{l}\text { *Riskli } \\
\text { davranış } \\
\text { biçimleri } \\
\text { *Hastalık }\end{array}$ & 3 & 3 & 9 & $\stackrel{\pi}{0}$ & $\begin{array}{l}\text { *Çalışanların hijyen ve Covid- } \\
\text { 19’a karşı doğru çalışma } \\
\text { biçimleri konusunda eğitim } \\
\text { alması sağlanmalıdır. }\end{array}$ \\
\hline
\end{tabular}


 \\ Tablo 5. (Devamı) Gerçekleştirilen Risk Analizi}

\begin{tabular}{|c|c|c|c|c|c|c|c|c|}
\hline 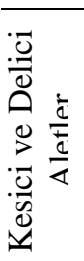 & 29 & $\begin{array}{l}\text { Kesici delici } \\
\text { aletlerin her } \\
\text { kullanimdan } \\
\text { önce ve sonra } \\
\text { kontrol } \\
\text { edilmemesi }\end{array}$ & $\begin{array}{c}\text { *Tahriş } \\
\text { *Kaza } \\
\text { *Yaralanma }\end{array}$ & 3 & 3 & 9 & $\stackrel{\pi}{0}$ & $\begin{array}{l}\text { *Çalışan ve müşteri sağlığını } \\
\text { korumak adına her kullanımdan } \\
\text { önce ve sonra kesici delici } \\
\text { aletlerin kontrolü } \\
\text { gerçekleştirilmelidir. *Uygun } \\
\text { olmayanları kullanılmamalıdır. }\end{array}$ \\
\hline 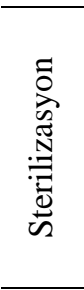 & 30 & $\begin{array}{l}\text { Tarak, cımbız, } \\
\text { manikür } \\
\text { araçları vb. } \\
\text { aletlerin her } \\
\text { kullanımdan } \\
\text { sonra steril } \\
\text { edilmemesi }\end{array}$ & $\begin{array}{l}\text { *Alerjik } \\
\text { reaksiyon } \\
\text { *Tahriş } \\
\text { *Kaza } \\
\text { *Yaralanma }\end{array}$ & 3 & 3 & 9 & $\stackrel{\pi}{0}$ & $\begin{array}{l}\text { *Çalışan ve müşteri sağlığını } \\
\text { korumak adına her kullanımdan } \\
\text { sonra ürünler steril edilmelidir. }\end{array}$ \\
\hline 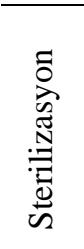 & 31 & $\begin{array}{l}\text { Sterilizasyon } \\
\text { cihazının } \\
\text { kullanma } \\
\text { talimatının } \\
\text { olmaması }\end{array}$ & $\begin{array}{l}\text { *Bilgi } \\
\text { eksikliği } \\
\text { *Kaza } \\
\text { *Yaralanma }\end{array}$ & 3 & 3 & 9 & $\stackrel{5}{0}$ & $\begin{array}{l}\text { *Cihazda doğru çalışma } \\
\text { yapılabilmesi ve olası kazaların } \\
\text { önüne geçilebilmesi için } \\
\text { sterilizasyon cihazı için kullanım } \\
\text { talimatı hazırlanmalı ve cihaz } \\
\text { yakınına asılmalıdır. }\end{array}$ \\
\hline $\begin{array}{l}\cdot \bar{\Xi} \\
\stackrel{\Xi}{0} \\
\stackrel{0}{00} \\
\dot{01}\end{array}$ & 32 & $\begin{array}{l}\text { Çalışanlara } \\
\text { yaptıkları işe } \\
\text { uygun sandalye } \\
\text { ya da destek } \\
\text { ekipmanı } \\
\text { sağlanmaması }\end{array}$ & $\begin{array}{c}\text { *Meslek } \\
\text { Hastalığı } \\
\text { *Kas iskelet } \\
\text { sistemi } \\
\text { rahatsızlıkları }\end{array}$ & 3 & 3 & 9 & $\stackrel{\pi}{0}$ & $\begin{array}{c}\text { *Çalışanlara fiziksel zorlanmayı } \\
\text { önlemek için yaptıklara işe uygun } \\
\text { sandalye ve destek ekipmanı } \\
\text { sağlanmalıdır. }\end{array}$ \\
\hline 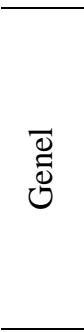 & 33 & $\begin{array}{l}\text { Giriş kapısı } \\
\text { zemininin } \\
\text { kayma ve } \\
\text { düşmeyi } \\
\text { önleyecek } \\
\text { ölçüde uygun } \\
\text { malzeme ile } \\
\text { kaplanmaması }\end{array}$ & $\begin{array}{c}\text { *Düşme } \\
\text { *Yaralanma }\end{array}$ & 3 & 3 & 9 & $\stackrel{\pi}{0}$ & $\begin{array}{l}\text { *Giriş kapısı zemininin kaymayı } \\
\text { ve düşmeyi önleyecek malzeme } \\
\text { ile kaplanmalıdır. } \\
\text { *Kaydırmaz bant uygulanmalıdır. } \\
\text { *Uyarı levhası konulmalıdır. }\end{array}$ \\
\hline 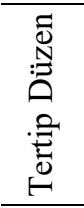 & 34 & $\begin{array}{l}\text { Saç kurutma } \\
\text { makinesinin } \\
\text { kablosunun } \\
\text { uygun } \\
\text { olmaması }\end{array}$ & $\begin{array}{c}\text { *Düşme } \\
\text { *Yaralanma }\end{array}$ & 3 & 3 & 9 & $\stackrel{\pi}{0}$ & $\begin{array}{l}\text { *Kullanılan elektrikli aletlerin } \\
\text { kabloları takılıp düşmeye mahal } \\
\text { vermeyecek ölçüde } \\
\text { toplanılmalıdır. }\end{array}$ \\
\hline 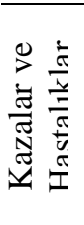 & 35 & $\begin{array}{l}\text { Çalışanların } \\
\text { periyodik } \\
\text { sağlık } \\
\text { muayenelerinin } \\
\text { yapılmaması }\end{array}$ & $\begin{array}{c}\text { *Meslek } \\
\text { Hastalı̆̆ı } \\
\text { *Çeşitli } \\
\text { akut/kronik } \\
\text { rahatsızlıklar }\end{array}$ & 3 & 2 & 6 & 竞 & $\begin{array}{l}\text { *İşyerinin tehlike sınıfına uygun } \\
\text { (4 yılda bir) ve mevzuat uyarınca } \\
\text { gerekli durumlarda tüm } \\
\text { çalışanların sağlık muayenesi } \\
\text { tekrarlanmalıdır. }\end{array}$ \\
\hline 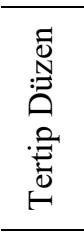 & 36 & $\begin{array}{c}\text { Çöplerin } \\
\text { biriktirilmesi }\end{array}$ & $\begin{array}{l}\text { *Kötü koku } \\
\text { oluşumu } \\
\text { *Çalışan } \\
\text { Sağlığını } \\
\text { Tehdit Etmesi }\end{array}$ & 5 & 1 & 5 & 言 & $\begin{array}{l}\text { *Çöpler ve atıklar belirlenen } \\
\text { düzenli aralıklarla çalışma } \\
\text { alanından uzaklaştırılmalıdır. } \\
\text { *Çalışanlara ilgili konuda eğitim } \\
\text { verilmelidir. }\end{array}$ \\
\hline 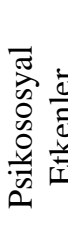 & 37 & $\begin{array}{l}\text { Çalışanlara } \\
\text { görev ve } \\
\text { sorumlulukları } \\
\text { haricinde } \\
\text { talimatların } \\
\text { verilmesi }\end{array}$ & $\begin{array}{l}\text { *İşten } \\
\text { soğuma } \\
\text { *B1kkınlık }\end{array}$ & 5 & 1 & 5 & בע & $\begin{array}{l}\text { *Çalışanlara görev ve } \\
\text { sorumlulukları haricinde } \\
\text { talimatlar verilmemelidir. }\end{array}$ \\
\hline
\end{tabular}


Tablo 5. (Devamı) Gerçekleştirilen Risk Analizi

\begin{tabular}{ccccccc}
\hline & $\begin{array}{c}\text { İsyerinde sigara } \\
\text { ve tütün } \\
\text { ürünlerinin } \\
\text { kullanılması }\end{array}$ & $\begin{array}{c}\text { *Zehirlenme } \\
* \text { Yangın }\end{array}$ & 1 & 5 & 5 \\
0
\end{tabular}

Yapılan risk analizi çalışmasında 14'ü katlanılamaz, 8'i önemli, 12'si orta ve 4'ü katlanılabilir olmak üzere toplamda 38 risk tespit edilmiştir.

Belirlenen risklerden; kullanılan kimyasalların bilgilendirici etiketlerinin olmaması, kimyasalların depolanmasının uygunsuz olması, acil çıkış kapısı ve yönlendirmelerinin olmaması, yangın merdiveninin olmaması gibi riskler dikkat çeken yüksek skorlu riskler arasındadır.
$\mathrm{Bu}$ çalışma ile kuaför salonlarında karşılaşılan tehlikeler ve riskler belirlenmiş ve ortam şartları, mevcut güvenlik önlemleri de dikkate alınarak puanlandırılmıştır. Belirlenen her bir risk için ülkemiz mevzuatı dâhilinde etkili, uygulanabilir güvenlik önlemleri önerilmiştir.

Çalışma bulguları neticesinde belirlenen sonuçların, kuaför salonları açısından anlamlı ve önemli olduğu görülmektedir.

\section{SONUÇ VE ÖNERILER}

$\mathrm{Bu}$ çalışmada 14'ü katlanılamaz, 8'i önemli, 12'si orta ve 4'ü katlanılabilir olmak üzere toplamda 38 risk tespit edilmiş ve aşağıda yer alan önerilerde bulunulmuştur.

- Kimyasalların çalışma alanından alınarak uygun bir depo alanı belirlenmesi ve bu alana taşınması, malzeme güvenlik bilgi formlarının temin edilmesi,

- Acil çıkış kapısı oluşturulması ve acil çıkışa götüren yolların uygun şekilde işaretlenmesi,

- İşletmeye ait mevcut durumun tespiti, acil durum eylem planı ve risk analizinin oluşturularak tatbikatların yapılması,

- Yangin tüplerinin düzenli kontrollerinin yapılarak görünür alanda standartlara zeminden max. $90 \mathrm{~cm}$ yukarıda konumlandırılması,

- Çalışanlara kişisel koruyucu donanımların temin edilmesi,

- İşletmede çalışanlara iş sağlığı ve güvenliği, ilk yardım ve hijyen konularında eğitimlerin verilmesi,
- Çalışanların sağlık kontrollerinin düzenli olarak yap1lmas1,

- Çalışanların/müşterilerin daha dikkatli olmalarını sağlayacak uyarı ve işaret levhalarının kullanılması,

- Kullanılan cihazların kullanım talimatlarının oluşturularak görülebilir alanlara konulmas1,

- Kullanılan kesici delici aletlerin her işlem bitiminde steril edilmesi ve kendilerine özel kılıflarına konularak kapalı alanlarda muhafaza edilmesi,

- Mevcut ilk yardım dolabina yeterli ve güncel tarihli malzemelerin temin edilmesi,

- Kullanılan elektrik kablolarının dağınık şekilde olmaması,

- Çalışmalarda yoğun kimyasal kullanımı sırasında havalandırma yeterli ölçüde sağlanmal,

- Covid-19 pandemisi başta olmak üzere salgın hastalıklara yönelik koruyucu önlemlere yönelik hareket edilmelidir. 


\section{KAYNAKLAR}

1. Bulduk, İ. (2018). "Kuaförlerde İs Güvenliği ve Sağlık Riskleri”. Mesleki Sağlık ve Güvenlik Dergisi, (68-69), 59-69.

2. EU-OSHA (European Agency for Safety and Health at Work). (2021). Risk assessment for hairdressers. Available

http://osha.europa.eu/en/publications/efacts/efact34.

3. El Batawi, M.A. (1974). "Health Hazards in Small Scale Industries - The Forgotten Masses". World Health, JulyAugust 4-8.

4. Omokhodion, F.O, Balogun, M.O. and Ola-Olorun, F.M. (2009). "Reported Occupational Hazards and Illnesses among Hairdressers in Ibadan, SouthWest Nigeria". West African Journal of Medicine, 28, (1).

5. Sahin, M. and Vapur, H. (2021). Ergonomic Risk Analysis With Reba and Rula Methods in Women's Hairdresser". ISSG Akademik, (3), 99-111.

6. Mussi, G. and Gouveia, N. (2008). "Prevalence of WorkRelated Musculoskeletal Disorders in Brazilian Hairdressers". Occupational Medicine, 58, 367-369.

7. Iorizzo, M, Parente, G, Vincenzi, C, Pazzaglia, M. and Tosti, A. (2002). "Allergic Contact Dermatitis in Hairdressers: Frequency and Source of Sensitization". European Journal of Dermatology, (12), 179-182.
8. Nixon, R, Roberts, H, Frowen, K. and Sim, M. (2006). "Knowledge of Skin Hazards and the Use of Gloves by Australian Hairdressing Students and Practising Hairdressers". Contact Dermatitis, 54, 112-116.

9. Sosyal Güvenlik Kurumu İstatistik Yillıkları. (2020). http://www.sgk.gov.tr/wps/portal/sgk/tr/kurumsal/istatist ik/sgk_istatistik_yilliklari, (Erişim tarihi:19.12.2020)

10. İș Sağlığı ve Güvenliği Kanunu. (2012). Resmi Gazete $28339,30 / 6 / 2012$

11. İş Sağlığı ve Güvenliğine İlişkin İşyeri Tehlike Sınıfları Tebliği. (2012). Resmi Gazete 28509, 26/12/2012.

12. İş Sağlığı ve Güvenliği Risk Değerlendirmesi Yönetmeliği. (2012). Yayımlandığı Resmi Gazete $28512,29 / 12 / 2012$.

13. Özkılıç, Ö. (2014). Risk Değerlendirmesi Atex Direktifleri-Patlayıc1 Ortamlar Büyük Endüstriyel Kazaların Önlenmesi ve Etkilerinin Azaltılmas1Kantitatif Risk Değerlendirme. Ankara: Türkiye İşveren Sendikaları Konfederasyonu TíSK.

14. İş Sağlığı ve Güvenliği Genel Müdürlüğü, https://www.ailevecalisma.gov.tr/isggm/hizmetlerimiz/y ayinlar/(Erişim tarihi: 24.11.2020). 